\title{
SIX SIGMA BUSINESS SCORECARD APPROACH TO SUPPORT MAINTENANCE PROJECTS IN A COLLABORATIVE CONTEXT
}

\author{
J. F. G. Requeijo ${ }^{1 *}$, A. J. P. C. F. Abreu ${ }^{2,3}$, J. M. F. Calado ${ }^{2,4}$, A. S. M. E. Dias ${ }^{2}$ \\ 1 UNIDEMI, Departamento de Engenharia Mecânica e Industrial, Faculdade de Ciências e Tecnologia, \\ Universidade Nova de Lisboa, 2829-516, Caparica, Portugal. \\ 2. Departamento de Engenharia Mecânica, Instituto Superior de Engenharia de Lisboa, 1959-007 Lisboa, \\ Portugal. \\ 3 CTS - Uninova - Instituto de Desenvolvimento de Novas Tecnologias \\ 4 IDMEC/LAETA, Instituto Superior Técnico - Universidade de Lisboa

$$
\text { *jfgr@fct.unl.pt }
$$

\section{RESUMO}

De acordo com a perspectiva tradicional a função manutenção é conotada como uma atividade secundária consumidora de recursos humanos e financeiros, razão pela qual, muitas empresas utilizam como estratégia de manutenção há já vários anos, a subcontratação dos serviços de manutenção a empresas especializadas. No entanto, a necessidade em efetuar operações de manutenção em sistemas cada vez mais complexos requer acesso a vários tipos distintos de competências que as pequenas e médias empresas especializadas em serviços de manutenção geralmente não possuem. Este artigo tem como objetivo ilustrar o papel da abordagem Six Sigma Scorecard como instrumento de gestão para a melhoria da qualidade no serviço prestado num contexto colaborativo. O artigo começa por discutir os princípios da filosofia Six Sigma e do Balanced Scorecard. Em seguida, é discutido de que modo se pode fazer a associação das duas metodologias como instrumento de gestão. Por último, é discutido como é que esta abordagem pode ser aplicada na avaliação das atividades de manutenção no contexto de um ecossistema colaborativo.

\section{SEIS SIGMA BUSINESS SCORECARD NO DESENVOLVIMENTO DE PROJETOS DE MANUTENÇÃO NUM CONTEXTO COLABORATIVO}

\begin{abstract}
According to the traditional perspective the maintenance function is counted as a secondary activity consuming human and financial resources, which is why many companies, use as maintenance strategy for several years, the subcontracting of maintenance services to specialized companies. However, the need to perform maintenance operations on increasingly complex systems requires access to several distinct types of skills that small and medium-sized firms specialized in maintenance services generally do not have. This paper aims to illustrate the
\end{abstract}

role of the Six Sigma Scorecard approach as a management tool for improving quality in service provided in a collaborative context. The article begins by discussing the principles of the Six Sigma and the Balanced Scorecard backgrounds. It is then discussed how the two methodologies can be combined as a management tool of maintenance activities. Finally, it is discussed how this approach can be applied in the assessment of maintenance activities in the context of a collaborative ecosystem.

KEYWORDS: Maintenance management, Six Sigma, Balanced Scorecard, Project management, Collaborative networks 


\section{INTRODUÇÃO}

Nowadays, the increasing evolution of the technology and the progressive automation of the equipment, nowadays designated by Industry 4.0, reveal a tendency for the sophistication and complexity of the productive processes. On the other hand, globalization has been the main driving force that makes companies need to operate at high levels of performance to ensure their survival.

The evolution of the methods and means of inspection that began to occur in the sixties, provided Maintenance Engineering with the development of fault prediction criteria and techniques, aiming at optimizing the performance of the maintenance execution teams. A new maintenance technique, called Predictive Maintenance, was observed, i.e. the maintenance action is only triggered when the symptoms indicate the proximity of the occurrence of malfunctions. It is as if the Maintenance had a crystal ball and the ability to predict the future, being able to determine with quantitative precision the date of the failure.

However, technological advances in equipment, which have been observed in recent years, the demands of quality, productivity and gains in international economic competitiveness, adding factors characterized by cost reduction and increased availability of equipment, have required the adoption of new work methodologies (Emovon et al, 2016).

As shown in Figure 1, the operational availability of the equipment is not only dependent on potential equipment downtime as a result of failures (Reliability and Maintainability) but also on the level of effectiveness and efficiency of the maintenance organization (resulting from competences of resources, availability of maintenance support equipment, spare parts, etc.) in the selection of the solution that is technically and economically more advantageous for a specific case (Bussel and Zaaijer, 2001; Szkoda, 2014).

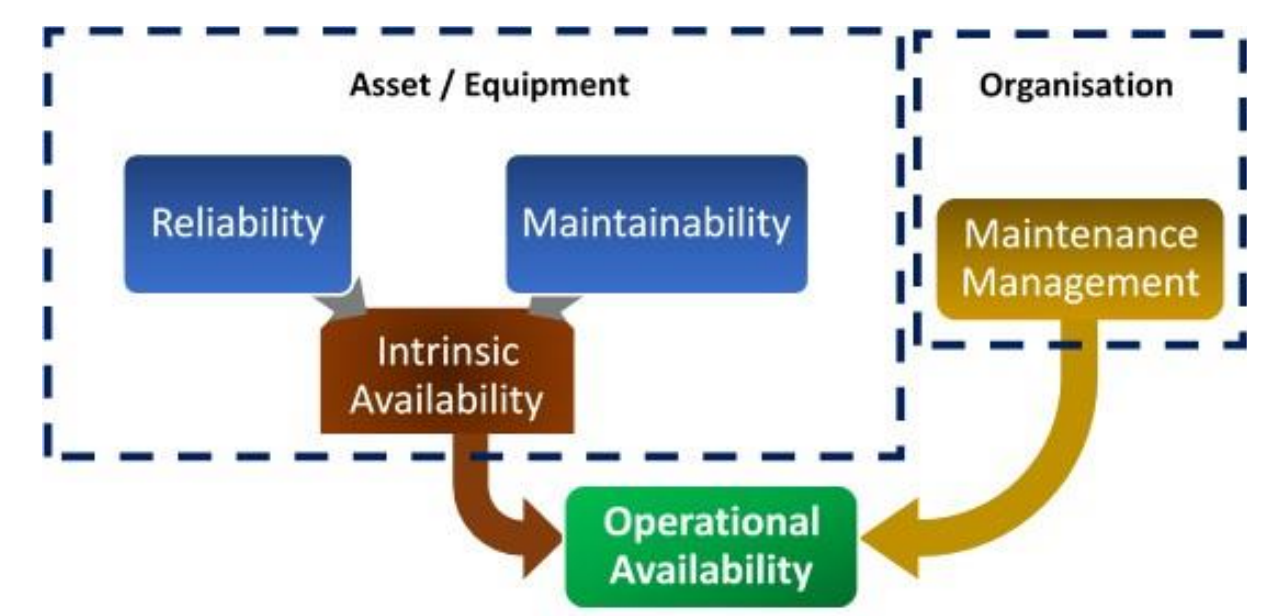

Figure 1: Factors influencing the operational availability of assets

The maintenance function has long since ceased to be considered a Costs Center, to assume the decisive position for the success of the Business, with characteristics of generator of profits for the companies in the so-called First World countries. We have entered the era of Total Quality, Proactive Maintenance, Intelligent Maintenance, Total Productive Maintenance, Lean Six Sigma Maintenance (Arslankaya and Atay, 2015; Abreu et al, 2016).

Maintenance is today a strategic area of development and is an important factor in the sustained growth of economies and their competitiveness. The performed maintenance activities proactively using means of detection and isolation of faults in real time will be a key contribution to 
the technological and social development of the industry, institutions and service providers, to ensure the competitiveness and survival of organizations.

The rapid technological innovation characteristic of contemporary economies has introduced increasingly sophisticated means of production, which translates into heavy losses whenever there are unscheduled outages, with a decisive impact on the profitability of companies (Tont et al, 2008) This reality requires the Maintenance to adopt a new, multidisciplinary, systemic position and concerned with achieving high periods between operational failures, as well as reducing the periods necessary to carry out the corresponding repair interventions for equipment and systems (Abreu $e t$ al, 2015).

It is verified that the new emergent reality imposes processes of continuous improvement of the organizations, which in regard to the activities of Maintenance requires the adoption of two complementary positions: projects that aim at a comprehensive and complete redesign of existing processes or the implementation of new processes, to be executed by multifunctional teams external to routine operations; systematic and sustained optimization activities, of the existing processes, carried out gradually by the teams in charge of routine operations.

On the other hand, the new paradigm imposed by the globalization of markets imposes on organizations and their agents an imperative need to acquire new skills and to promote profound changes in work processes and corresponding management mechanisms.

The search for efficient and effective business performance, especially when inserted in competitive and turbulent environments, can only be achieved through the adoption of strategies that have an integrated vision of organizational networks, with adequate flexibility and connectivity that ensure a rapid response in the processes planning, management and technical-administrative operation whenever this is necessary (Abreu and Camarinha-Matos, 2014) (Requeijo and Abreu, 2013).

As a company of a modern and dynamic industry (aerospace and defense), Embraer, together with ATR (a company linked to EADS, mainly French and Alenia - Italiana), decided to develop a collaborative ecosystem that provides after sales services and collaboration in the value chain, called AEROChain. This ecosystem links the aerospace industry to the defense industry, bringing suppliers, customers and strategic partners together on the Internet. The main reason for the creation of this network was the search for greater efficiency in the management of the whole value chain (from aviation companies to aircraft manufacturers and from those to equipment manufacturers and other suppliers in the industry). It should be noted that all processes, systems, and communication channels have had to be redesigned to respond adequately to the emerging requirements of this industry. AEROChain also provides updated technical and operational publications to manufacturers and suppliers around the world.

This paper aims to illustrate the role of the Six Sigma Scorecard approach as a management tool for improving quality in the service provided. It begins by addressing the principles of the Six Sigma and the Balanced Scorecard philosophies. Then, it is discussed how the two methodologies can be associated as a management tool to improve process performance. Finally, it is discussed how this approach can be applied in evaluating the performance of maintenance operations in the context of a collaborative ecosystem, thus contributing to customer satisfaction and to the sustainability of organizations. 


\section{PRINCIPLES OF SIX SIGMA}

Usually, organizations/companies define technical specifications, by quality characteristic, in order to meet the implicit or explicit needs of future customers/consumers. These specifications, defined at the design stage of the products or services and their processes, are almost always quantifiable on a continuous scale. Thus, it is possible to set up an information collection procedure (data) in each production process, analyse the data and characterize the process. The meaning of the term "characterization of the process", which is to be emphasized, has to do with the clear identification of the way in which it takes place, i.e., to know with high reliability that the values of the characteristic under study have a certain average value and a determined dispersion, as well as the type of distribution associated with such data. In order to define and perform a suitable "process characterization", it is common to use a set of tools, such as flowcharts, data logging, control charts and histograms (Requeijo et al, 2014). The analysis of the capacity of the processes to suit their technical specifications is traditionally done using the so-called process capability indexes, such as the index $C_{p}$ and the index $C_{p k}$. Whereas the process for a certain quality characteristic follows a Normal distribution with average $\mu$ and standard deviation $\sigma$, these indices are defined by:

$$
\begin{aligned}
& C_{p}=\frac{U S L-L S L}{6 \sigma} \\
& C_{p k}=\min \left(C_{p k I}, C_{p k S}\right) \\
& C_{p k S}=\frac{U S L-\mu}{3 \sigma} \text { and } C_{p k I}=\frac{\mu-L S L}{3 \sigma}
\end{aligned}
$$

Traditionally, for bilateral specifications, it is considered that a process is capable of producing according to its technical specification, when the values of $C_{p}$ and $C_{p k}$ are greater than 1.33. This value of 1.33, means that $L S L$ (lower specification limit) and $U S L$ (upper specification limit) are at least $4 \sigma$ away from the average $\mu$ of the process. The situation of the specification limits to be at $4 \sigma$ away from the average $\mu$ of the process, happens in the ideal condition of the process, i.e., the process is centred with the specification $\left(C_{p k l}=C_{p k S}\right)$. For a better understanding of this subject, it is suggested, the reading of Pereira e Requeijo (2008), Montgomery (2009), Ryan (2011), between others.

A process centred with $C_{p k}=1.33$ produces 60 units in one million units produced. This value is calculated taking into account the location of the specification limits ( $4 \sigma$ away from the average $\mu$ ), considering that the distribution of the quality characteristic under study is Normal. This situation is illustrated in Figure 2.

Considering that a complex product consists of 50 components and that all components present $C_{p k}=1.33$, nonconforming production shall be equal to $(0.99994)^{50}=0.9970$. This means that the proportion of nonconforming production will be equal to 0.003 , i.e., the production of 3 nonconforming units in 1000 units produced. Although this figure corresponds to the most favorable situation, even so, for certain products it may be considered unacceptable.

At the end of the 80's the methodology/philosophy known as Six Sigma was developed at Motorola. This methodology presents the limit value of 3.4 per million as an admissible value for non-compliant production. It identifies "two states" in a productive process, the first called "short term" and the second "long term". 


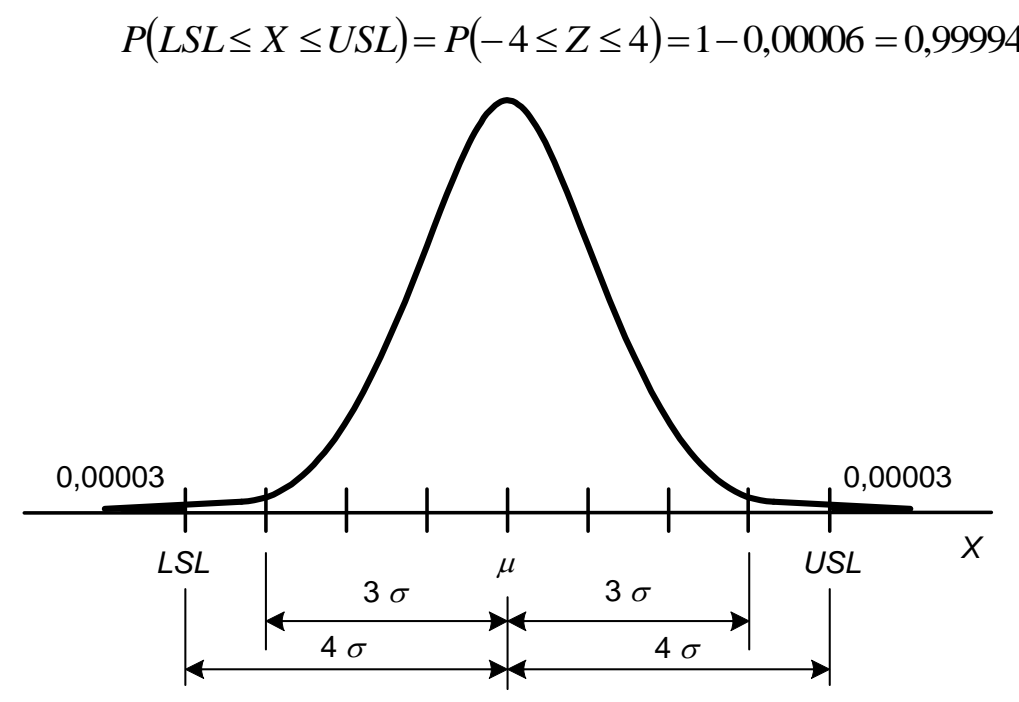

Figure 2: Non-compliant production for a process centred on $C_{p k}=1.33$

In the first, it is considered that the process is stable and the devices produced have an average $\mu$ and standard deviation $\sigma$. In the second, it is understood that unidentified variations can occur in the process when the process is in the "short-term" state and as a consequence it is assumed that the process average can fluctuate from $\pm 1,5 \sigma$. As a result of these reclaims, the quality level (sigma level) of a given process is expressed in terms of $\sigma$. In order to identify what level of quality a particular process presents, it is only necessary to determine the number of nonconforming units in one million units produced. In the Six Sigma philosophy, in order to make it more comprehensive, several metrics are used, such as: Defects Per Unit (DPU), Defects Per Opportunity (DPO) and Defects Per Million of Opportunities (DPMO).

$$
\begin{aligned}
& \text { DPU }=\frac{\text { total number of defects }}{\text { number of units checked }} \\
& \text { DPO }=\frac{\text { total number of defects }}{\text { number of units checked } \times \text { number of defect opportunities }}
\end{aligned}
$$

$D P M O=D P O \times 10^{6}$

Table 1 shows the values of DPMO that allow to identify the quality level of a process (the perspective assumed in this paper considers the number of nonconforming units, whereby $1 D P M O$ $=1$ nonconforming unit). For a better understanding of this subject, it is suggested, the reading of Park (2003), between others.

Overall, one of the goals of any maintenance company when conducting a maintenance project is to ensure that the service provided for the maintenance of the equipment or facility that is the object of intervention has occurred without defects or failures, i.e., the customer's specifications have been satisfied. 
Table 1: Conversion table for scale Sigma

\begin{tabular}{|c|c|c|c|c|c|c|c|c|c|}
\hline $\begin{array}{c}\text { Scale } \\
\text { Sigma }\end{array}$ & DPMO & $\begin{array}{c}\text { Scale } \\
\text { Sigma }\end{array}$ & DPMO & $\begin{array}{c}\text { Scale } \\
\text { Sigma }\end{array}$ & DPMO & $\begin{array}{c}\text { Scale } \\
\text { Sigma }\end{array}$ & DPMO & $\begin{array}{c}\text { Scale } \\
\text { Sigma }\end{array}$ & DPMO \\
\hline 0,00 & 933193 & 1,20 & 617911 & 2,40 & 184060 & 3,60 & 17864 & 4,80 & 483 \\
\hline 0,05 & 926471 & 1,25 & 598706 & 2,45 & 171056 & 3,65 & 15778 & 4,85 & 404 \\
\hline 0,10 & 919243 & 1,30 & 579260 & 2,50 & 158655 & 3,70 & 13903 & 4,90 & 337 \\
\hline 0,15 & 911492 & 1,35 & 559618 & 2,55 & 146859 & 3,75 & 12224 & 4,95 & 280 \\
\hline 0,20 & 903200 & 1,40 & 539828 & 2,60 & 135666 & 3,80 & 10724 & 5,00 & 233 \\
\hline 0,25 & 894350 & 1,45 & 519939 & 2,65 & 125072 & 3,85 & 9387 & 5,05 & 193 \\
\hline 0,30 & 884930 & 1,50 & 500000 & 2,70 & 115070 & 3,90 & 8198 & 5,10 & 159 \\
\hline 0,35 & 874928 & 1,55 & 480061 & 2,75 & 105650 & 3,95 & 7143 & 5,15 & 131 \\
\hline 0,40 & 864334 & 1,60 & 460172 & 2,80 & 96800 & 4,00 & 6210 & 5,20 & 108 \\
\hline 0,45 & 853141 & 1,65 & 440382 & 2,85 & 88508 & 4,05 & 5386 & 5,25 & 88 \\
\hline 0,50 & 841345 & 1,70 & 420740 & 2,90 & 80757 & 4,10 & 4661 & 5,30 & 72 \\
\hline 0,55 & 828944 & 1,75 & 401294 & 2,95 & 73529 & 4,15 & 4025 & 5,35 & 59 \\
\hline 0,60 & 815940 & 1,80 & 382089 & 3,00 & 66807 & 4,20 & 3467 & 5,40 & 48 \\
\hline 0,65 & 802337 & 1,85 & 363169 & 3,05 & 60571 & 4,25 & 2980 & 5,45 & 39 \\
\hline 0,70 & 788145 & 1,90 & 344578 & 3,10 & 54799 & 4,30 & 2555 & 5,50 & 32 \\
\hline 0,75 & 773373 & 1,95 & 326355 & 3,15 & 49471 & 4,35 & 2186 & 5,55 & 26 \\
\hline 0,80 & 758036 & 2,00 & 308538 & 3,20 & 44565 & 4,40 & 1866 & 5,60 & 21 \\
\hline 0,85 & 742154 & 2,05 & 291160 & 3,25 & 40059 & 4,45 & 1589 & 5,65 & 17 \\
\hline 0,90 & 725747 & 2,10 & 274253 & 3,30 & 35930 & 4,50 & 1350 & 5,70 & 13 \\
\hline 0,95 & 708840 & 2,15 & 257846 & 3,35 & 32157 & 4,55 & 1144 & 5,75 & 11 \\
\hline 1,00 & 691462 & 2,20 & 241964 & 3,40 & 28717 & 4,60 & 968 & 5,80 & 9 \\
\hline 1,05 & 673645 & 2,25 & 226627 & 3,45 & 25588 & 4,65 & 816 & 5,85 & 7 \\
\hline 1,10 & 655422 & 2,30 & 211855 & 3,50 & 22750 & 4,70 & 687 & 5,90 & 5 \\
\hline \multirow[t]{2}{*}{1,15} & 636831 & 2,35 & 197663 & 3,55 & 20182 & 4,75 & 577 & 5,95 & 4 \\
\hline & & & & & & & & 6,00 & 3 \\
\hline
\end{tabular}

Assuming that defects can occur randomly and independently of each other, we may in these circumstances resort to the Poisson distribution, in order to calculate the probability of occurrence of failures/defects in a given time interval:

$$
P(x)=\frac{\mu^{x} e^{-\mu}}{x !}
$$

Where:

$P(x)$ - Probability of occurrence of $\mathrm{x}$ defect(s)/failure(s) in the maintenance of a equipment;

$\mu$ - average number of defects / failures per equipment, asset that has undergone a maintenance intervention.

Thus, in the context of maintenance management, the unit is defined as the equipment, that is, the asset that undergoes a maintenance intervention. Then, the Defects Per Unit (DPU) metric is defined by:

$$
\mathrm{DPU}=\frac{\text { number of defects }}{\text { number of equipments that undergoes a maintenanc e interventi on }}
$$

So, doing $\mu=D P U$ the probability of a maintenance project being carried out without any defect is given by:

$$
P(0)=\frac{D P U^{0} e^{-D P U}}{0 !}=e^{-D P U}
$$


If we consider that any maintenance project consists of a sequence of processes, the probability of an equipment passing through one of the sequentialy maintenance processes without fail is given by (Baas, 2007) (Gupta, 2004):

$$
P(0)=e^{-D P U}
$$

Representing this probability by $y$, as the probability of an equipment passing the first maintenance process without fail, the following equation can be written:

$$
y=e^{-D P U}
$$

Thus, if the probability of successful execution is known, that is, without failures in the first process of maintaining the equipment of the entire sequence of defined processes, it is possible to determine the value of DPU by the following equation:

$$
D P U=-\ln (y)
$$

As shown in Figure 3, in overall terms and from the macro viewpoint a maintenance project of an equipment comprises several steps / process sequences.

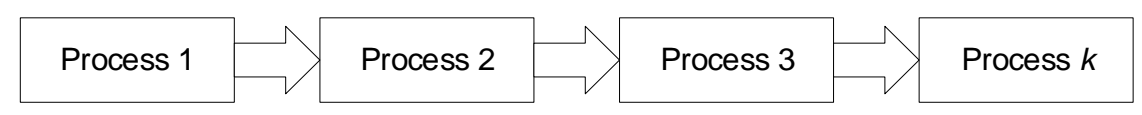

Figure 3: Maintenance Project

Therefore, the probability of an equipment to overcome a set of $k$ steps/sequence processes without any failure in the set of processes can be determined by:

$$
Y_{\text {Global }}=\prod_{n=1}^{k} y_{n}
$$

Thus, the DPU value for the entire maintenance project can be determined by:

$$
D P U_{P M}=-\ln \left(Y_{P M}\right)
$$

Then, the DPU value for the entire maintenance project could be given by:

$$
D P U_{P M}=-\ln \left(Y_{P M}\right)=-\ln \left(\prod_{n=1}^{m} y_{n}\right)=-\sum_{n=1}^{m} \ln \left(y_{n}\right)=\sum_{n=1}^{m} D P U_{n}
$$

\section{BALANCED SOCORECARD}

Nowadays, in an accelerated and highly competitive world, measurement is the first step that leads to control and eventually process improvement. If you do not measure, you do not understand. If you do not understand, you cannot control and if you cannot control, you will not be able to improve. On the other hand, what we measure is not indifferent, not neutral. What we measure 
reflects what we value and in that sense, is a powerful signal that is transmitted throughout the company (Muchiri et al,2013). In this sense, the monitoring of the performance of processes based exclusively on financial indicators has become insufficient. The development of holistic management support tools that allow the evaluation and monitoring of company performance based on a defined strategy is an imperative of modern management.

Developed by Robert Kaplan and David Norton (2001), the Balanced Scorecard (BSC) is characterized by being a structured model that not only complements the traditional financial indicators but also relates the long-term strategy to short-term interventions. Thus, the BSC offers a dashboard of business management tools, supported by financial indicators that translate the results of actions and decisions taken, and in non-financial indicators on customer satisfaction, internal business processes, innovation activities and continuous improvement of the processes, related to the critical success factors of the business, as shown in Figure 4.

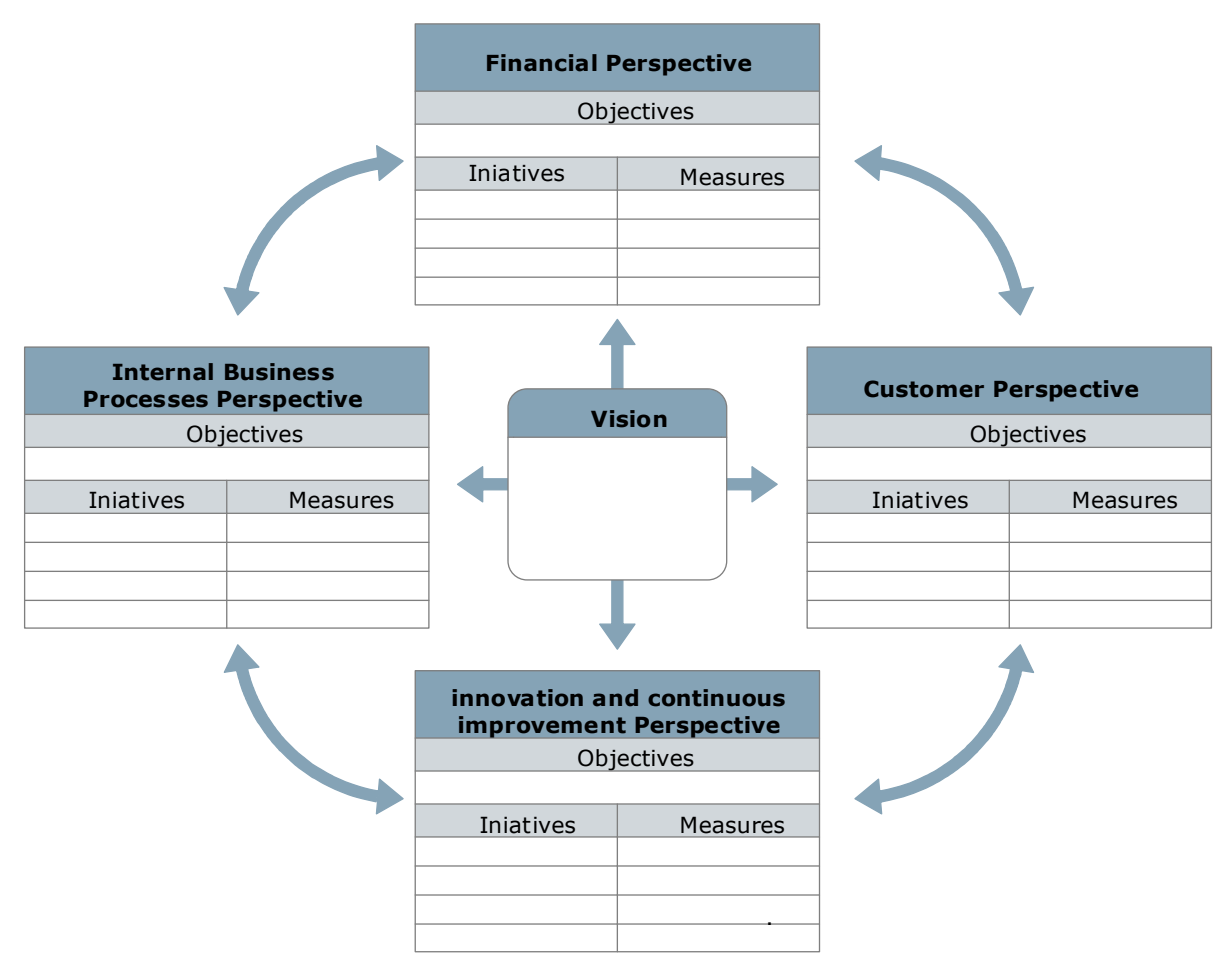

Figure 4: BSC Control Panel

According to the financial perspective, the indicators developed aim to answer the following question: - How are we seen by stakeholders? In the customer perspective, the indicators allow the company to answer the question - How are we perceived by customers? From the perspective of internal processes, the indicators allow the company to answer the question - Where do we have to be excellent? From the perspective of innovation and continuous improvement, the indicators allow the company to answer the question - Where should we continue to improve and create value? In this way the BSC functions as a dashboard, which allows management to have a comprehensive view of the company's performance in the short and medium term. 


\section{SIX SIGMA BALANCED SCORECARD}

Based on the philosophy of Six Sigma and the BSC approach, Praveen Gupta proposed a Six Sigma Business Scorecard methodology (Gupta, 2004) (Gupta, 2006). This approach aims to build a dashboard that allows management to monitor company performance based on the dimensions of the Balanced Scorecard but through the Six Sigma levels.

Based on this approach, both the outcomes of actions and decisions taken that are evaluated in financial terms, and the critical success factors of the business that are analyzed from a nonfinancial perspective, their unmatched performance is quantified through Six Sigma levels.

Thus, an indicator, called business performance index, was developed as a measure of the overall performance of the system (SPI), which can go from a department to the company itself, and from this indicator determine the corresponding Six Sigma level. Thus, the determination of the sigma level comprises the following steps:

- Definition of the indicators to be measured - Os indicadores deverão ser seleccionados de acordo com os objectivos que foram definidos e as especificidades das actividades de manutenção a desenvolver de modo a garantir que todas as pespectivas consideradas relevantes pela gestão sejam objecto de monitorização.

- Definition of weights $P_{n}$ to be attributed to each of the indicators according to the relative importance of each of them for the success of the objectives that have been defined. The sum of all weights must be equal to 100 .

- Measuring the performance of each indicator: for each of the $n$ indicators, the performance is calculated by the following ratio:

$\mathrm{D}_{\mathrm{n}}=\frac{\text { performance achieved } \times 100}{\text { performance predicted }}$

- Determination of Partial Performance Indexes (PPI) for each of the $\mathrm{n}$ indicators. These indexes are determined by the following equation:

$$
P P I_{n}=\frac{P_{n} \times D_{n}}{100}
$$

- Determining the overall System Performance Index (SPI), through the following equation:

$$
S P I=\sum_{n=1}^{10} P P I_{n}
$$

- Determination of the DPU by the following equation:

$$
D P U_{\text {Global }}=-\ln \left(\frac{S P I}{100}\right)
$$

In this case it is considered that the value of SPI corresponds to the system as a whole, in a way analogous to that given by equation (14).

- Determination of the DPMO by the following equation:

$$
\mathrm{DPMO}_{\mathrm{PM}}=\frac{\mathrm{DPU}_{\mathrm{PM}} \times 10^{6}}{\text { number of processes }}
$$

By definition of the DPMO (see equations (5) and (6)) the denominator comes as the number of defect opportunities, that is, the total number of possibilities to have defects or making mistakes. Thus, in a maintenance project, from the point of view of operational management, it is assumed 
that the opportunities for defect are associated with the non-compliance with the specifications associated with each process.

- Determining the Six Sigma level through the Table 1.

In order to illustrate the sigma level associated with a maintenance project, Table 2 illustrates the indicators that were used, as well as the values obtained in this hypothetical case.

Table 2: Determining the Six Sigma level for a hypothetical case of a maintenance project

\begin{tabular}{|c|c|c|c|}
\hline Measured indicators & $P_{n}$ & $D_{n}$ & $P P I_{n}$ \\
\hline I1. Costs & 20 & 80 & 8 \\
\hline I2. Scope & 15 & 70 & 10,5 \\
\hline I3. Deadlines & 15 & 60 & 9,6 \\
\hline I4. Suppliers Failure Rate & 10 & 60 & 6 \\
\hline I5. Technological Capacity & 10 & 70 & 7 \\
\hline I6. Operational availability of equipments & 10 & 70 & 7 \\
\hline I7. Hours of work subcontracted & 5 & 75 & 3,75 \\
\hline I8. Processes defects rate & 5 & 60 & 3 \\
\hline I9. Capacity available & 5 & 70 & 3,5 \\
\hline I10. Customer Satisfaction Level & 5 & 90 & 4,5 \\
\hline \multicolumn{4}{|c|}{ Calculations } \\
\hline SPI & \multicolumn{3}{|c|}{$62,85 \%$} \\
\hline DPU $U_{\text {Global }}$ & \multicolumn{3}{|c|}{0,4644} \\
\hline Number of processes & \multicolumn{3}{|c|}{15} \\
\hline DPMO & \multicolumn{3}{|c|}{30960} \\
\hline Six Sigma level & \multicolumn{3}{|c|}{3,35} \\
\hline
\end{tabular}

The process of measuring the performance of each of the indicators is not discussed in this paper, however, their calculation are based on the perception of the employees involved in the project or alternatively through tools, for instance application of fuzzy logic (Abreu e Calado, 2017), which allow a more objective way to assess the differences between previously planned results and the actual results.

However, based on the values in Table 2, as well as in the obtained values resulting from the application of the equations previously defined, we can verify that the closer the real values are of the values initially established, the value of $D_{n}$ approaches the $100 \%$ and if all indicators have a performance of $100 \%$ the value of $\mathrm{DPU}_{\mathrm{Global}}$ of the project would be zero, it could be stated that the maintenance project in question had been perfect in every perspective in view of the objectives initially defined.

\section{INCREASE THE SERVICE LEVEL OF MAINTENANCE PROCESSES THROUGH COOPERATION RELATIONS}

Companies, to be competitive in markets increasingly demanding, should adopt strategies that allow them to provide high quality services to their customers. When a company intends to 
provide complex maintenance services, the company has two possible alternatives: to internally develop the necessary resources both in terms of management skills and operational skills in order to ensure a quality standard acceptable to the customer and does not compromise its sustainability and survival in the market, or alternatively choose to carry out the maintenance project in a collaborative context (Camarinha-Matos and Abreu, 2005).

The approach followed in this paper assumes the existence of a collaborative ecossistem as a pre-condition for the effective establishment of collaborative maintenance projects. A collaborative ecossistem represents an association or pool of organizations and companies and their related supporting institutions that have both the potential and the will to cooperate with each other through the establishment of a "base" long-term cooperation agreement. When a business opportunity is identified by one member (acting as a coordinater), a subset of these organizations can be selected and thus forming a collaborative network. Various collaboratives networks can coexist at the same time in the context of a collaborative ecossistem. A collaborative ecosystem, being a long-term networked structure, presents the adequate base environment for the establishment of cooperation agreements, common infrastructures, common ontologies, and mutual trust, which are the necessary facilitating elements when building a new collaborative maintenance project. In other words, a collaborative ecossistem represents a group of organizational entities that have developed a preparedness for cooperation, in case a specific opportunity arises. Industry clusters or industry districts are examples of such collaborative ecossistems.

The existence of this long-term environment can also provide the basis to record performance data about past collaborative maintenance projects, a source for computation of performance indicators. In this context, the choice of the partners to carry out the necessary processes will depend on the identification of the companies that present the highest levels of sigma performance for the set of processes assigned to them. Thus, if this principle is present in the process of creating the collaborative network, companies will be able to increase their competitiveness in the face of competition and ensure their own survival in a faster and less impacted way.

However, the success of this approach requires the development of a tool that supports the management activities and the existence of mechanisms that act as incentives for collaboration and punish the infractors (Ahmed et al, 2007) (Tenera and Abreu, 2008) (Camarinha-Matos et al, 2008). Futhermore, the companies involved in a collaborative network must provide to the member coordinater, reliable information in useful time during the execution of the maintenance project; as well as, when was necessary to participate effectively in the recovery of delays.

Figure 5 illustrates from the operational point of view the sequence of operations associated with a collaborative maintenance project and the operations associated with the internal maintenance project carried out by each of the partners.

To illustrate the advantages of establishing collaborative networks as a way of increasing the quality of the maintenance service provided, consider the following scenario: four independent companies form a cluster of companies to provide maintenance services, as shown in Figure 6; have received from their clients four projects to maintain their equipment where it is necessary to ensure a certain level of quality according to the indicated sigma level, so that the project is successful, both at management level and operational level, thus ensuring not only customer satisfaction as well as company sustainability.

For the sake of simplification, the use of other procedures would not be considered, which would also allow the provision of maintenance services with the same characteristics /functionalities. 


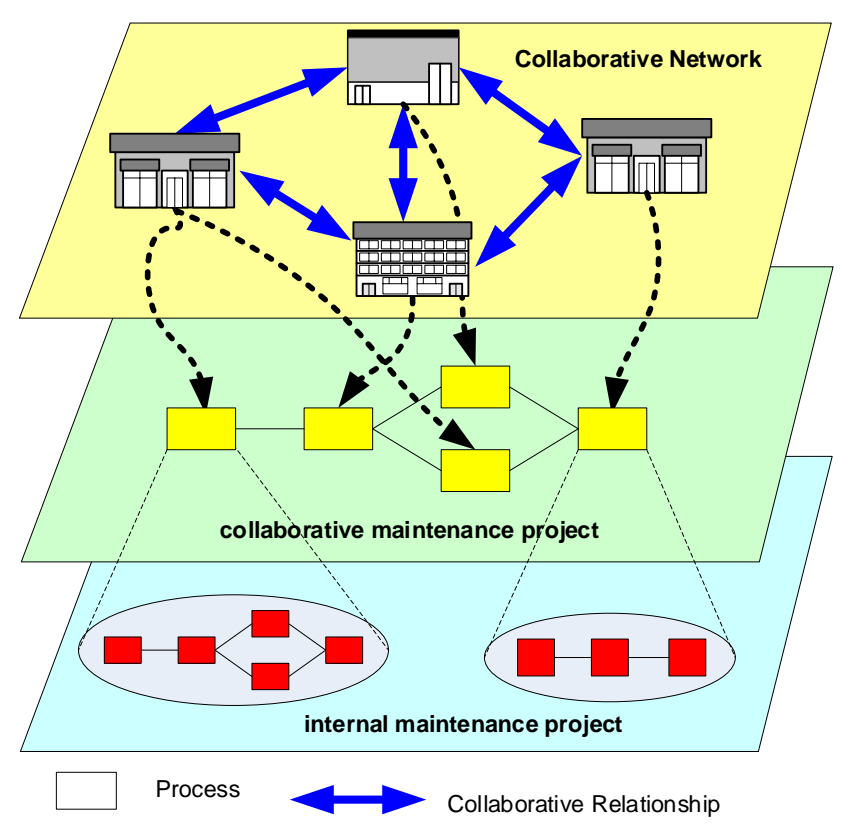

Figure 5: Example of a network of a collaborative maintenance project

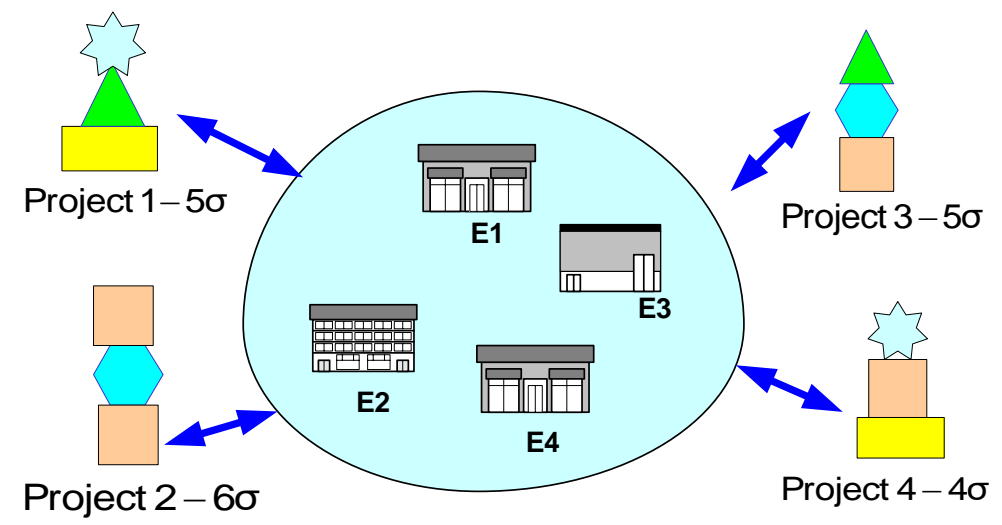

Figure 6. Example of cooperation between several companies

Figure 7 illustrates for the various companies the hypothetical sigma-level matrix for the processes required to complete each maintenance project based on historical performance on similar projects.

\begin{tabular}{|c|c|c|c|c|c|}
\hline & P1 & $\mathbf{P 2}$ & P3 & P4 & P5 \\
\hline & $L$ & $\square$ & & $\{w$ & $\Delta$ \\
\hline E1 & $5 \sigma$ & $4 \sigma$ & $3 \sigma$ & $3 \sigma$ & $5 \sigma$ \\
\hline E2 & $5 \sigma$ & $6 \sigma$ & $4 \sigma$ & $4 \sigma$ & $3 \sigma$ \\
\hline E3 & $5 \sigma$ & $4 \sigma$ & $5 \sigma$ & $5 \sigma$ & $6 \sigma$ \\
\hline E4 & $6 \sigma$ & $5 \sigma$ & $6 \sigma$ & $5 \sigma$ & $4 \sigma$ \\
\hline
\end{tabular}

Figure 7: Sigma level associated with the process capability matrix for the various components 
In this case, if there is no cooperation agreement between the companies, only E4 can carry

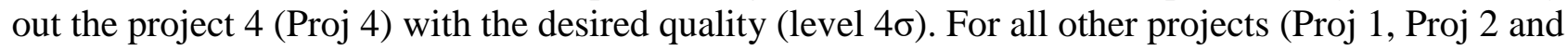
Proj 3) none of the companies has the capacity to perform them in a way that assures the customers' requirements and without compromising the company's sustainability, as shown in Figure 8.

\begin{tabular}{|c|c|c|r|r|r|r|}
\cline { 4 - 7 } \multicolumn{2}{c}{} & \multicolumn{4}{c|}{$\begin{array}{c}\text { Level of service provided by each } \\
\text { company }\end{array}$} \\
\hline Project & $\begin{array}{c}\text { Service Level } \\
\text { required }\end{array}$ & $\begin{array}{c}\text { Processes } \\
\text { required }\end{array}$ & E1 & E2 & E3 & E4 \\
\hline Proj 1 & 5 & P1- P5-P3 & 3 & 2,92 & 3,99 & 3,74 \\
Proj 2 & 5,5 & P1- P2-P1 & 3,97 & 4,81 & 3,97 & 4,99 \\
Proj 3 & 5 & P5- P2-P1 & 3,97 & 3 & 3,99 & 3,99 \\
Proj 4 & 4 & P4- P1-P3 & 3 & 3,74 & 3,97 & 4 \\
\hline
\end{tabular}

Figure 8: Quality Level provided by each company

In the case of establishing a collaborative process between the four companies, all maintenance projects are carried out according to the quality required by the clients and without compromising the sustainability of the companies. Figure 9 presents the quality level, in the sigma scale, that can be achieved for each of the maintenance projects, as well as the cooperation to be carried out between the 4 companies to carry out the four maintenance projects.

\begin{tabular}{|c|c|c|c|c|}
\hline Project & $\begin{array}{c}\text { Service Level } \\
\text { required }\end{array}$ & $\begin{array}{c}\text { Cooperation } \\
\text { process }\end{array}$ & $\begin{array}{c}\text { Collaborative } \\
\text { Network }\end{array}$ & $\begin{array}{c}\text { Collaborative } \\
\text { service level }\end{array}$ \\
\hline Proj 1 & 5 & P1- P5-P3 & E1-E3-E4 & 4,99 \\
Proj 2 & 5,5 & P1- P2-P1 & E4-E2-E4 & 5,76 \\
Proj 3 & 5 & P5- P2-P1 & E3-E2-E4 & 5,76 \\
Proj 4 & 4 & P4- P1-P3 & E1-E4-E4 & 4,99 \\
\hline
\end{tabular}

Figure 9: Quality level of the cooperation process for the various maintenance projects

As for the causes of the increase in the service level of the maintenance processes performed associated with the maintenance activities carried out in a collaborative context, these can be of a quantitative nature (e.g. reduction of maintenance costs, reduction of maintenance intervention times) or qualitative as for example the development of innovative solutions, technology transfer, among others. On the other hand, any of the two types of service level increase can be obtained by performing a set of qualitative and quantitative activities. Thus, we can identify four different situations as shown in Table 3.

Table 3 - Nature of activities and their effect on increasing the level of service provided

\begin{tabular}{|c|c|c|c|}
\hline & & \multicolumn{2}{|c|}{ Types of service level increase } \\
\hline & & quantitative nature & Qualitative nature \\
\hline \multirow{2}{*}{$\begin{array}{c}\text { Majority of the } \\
\text { activities involved in a } \\
\text { collaborative context }\end{array}$} & $\begin{array}{c}\text { quantitative } \\
\text { nature }\end{array}$ & $\begin{array}{c}\text { addition or complementarity } \\
\text { effect }\end{array}$ & critical mass effect \\
\hline & $\begin{array}{c}\text { Qualitative } \\
\text { nature }\end{array}$ & Catalytic effect / coordination & $\begin{array}{l}\text { addition or complementarity effect } \\
\text { (inside information) }\end{array}$ \\
\hline
\end{tabular}


Let us consider the activities involved in the cooperation when the increase in the level of service obtained is of a quantitative nature. In this case the cooperation process has an addition or complementarity effect. To illustrate the addition effect, let us assume that a company receives a request from a customer to perform a major maintenance intervention in a complex installation within a pre-established time period and does not have sufficient capacity to execute it. As a way of overcoming the lack of capacity, the company seeks to establish a cooperation agreement with another company, so that, by a process of adding capacity, the company that owns the business has the necessary conditions to carry out the requested maintenance intervention within the defined deadlines. In relation to the complementary effect, this occurs when the cooperation process aims to carry out complementary activities, for example, one company performs the technical tests of control and the other performs the replacement of the damaged components.

Let us now consider the situations where the activities involved in the cooperation are of a quantitative nature and the increase in the level of service obtained is of a qualitative nature. In this case the cooperation process has a similar effect to the concept of critical mass used in physics and chemistry and occurs when there is a nonlinear relation between the resources used by the partners in the cooperative process and the qualitative results obtained. It is the situation of research processes where it is often necessary to gather a minimum number of experts (critical mass) to solve a complex problem.

Other situations are when the activities involved in the cooperation are qualitative and the increase in the level of service obtained is of a quantitative nature. In this case the cooperation process has a similar effect to the catalytic phenomena that occur in the field of chemistry. Thus, when a company shares a certain competence with another, this competence produces a quantitative increase in the level of service provided due to the increased efficiency in performing the maintenance operations.

Finally, we are going to consider the situations where the activities involved in the cooperation are qualitative and the increase in the level of service obtained is of a qualitative nature. This is the case, for example, when two companies have incomplete information on how a particular maintenance intervention should be carried out and a process of information exchange, obtains a better knowledge of the failure modes that must be analysed.

\section{CONCLUSIONS}

Currently, there seems to be unanimity on the part of the various actors involved in the business world that, in order to survive, SMEs (small and medium-sized enterprises) increasingly have to develop business strategies that allow them to move towards a greater appreciation of the products/services provided to their clients, such as the development of improvement projects supported in Lean Six Sigma programs.

However, implementing these strategies in many cases requires skills and investments for which companies are not normally prepared, such as small and medium-sized enterprises.

In this context, as an alternative, it has been shown how, through dynamic cooperation networks, a company can significantly increase its level of competitiveness, at a reduced cost and in a practically instantaneous time, which in turbulent socio-economic scenarios represents an additional advantage in relation to traditional improvement processes.

So, companies must have the lucidity, otherwise these days it can be fatal, that when faced with certain needs or requirements of the client, shall have the humility to assume that "My process does not allow to meet the desired requirements, but in collaboration with other companies we can take care of your request, if the customer continues to be interested". This is the emerging paradigm 
in several sectors of activity, including companies engaged in general maintenance activities, and in particular industrial maintenance activities.

\section{ACKNOWLEDGEMENTS}

This work was partially funded by Portuguese Funds through the Foundation for Science and Technology-FCT under the project LAETA 2015-2020, reference UID/EMS/50022/2013.

\section{REFERENCES}

ABREU, A.; CALADO, J. M. F., A fuzzy logic model to evaluate the lean level of an organization. International Journal of Artificial Intelligence and Applications (IJAIA), v.8, n.5, 2017

ABREU, A.; CALAdO, JOÃO; REQUEIJO, JOSÉ., Buildings Lean Maintenance Implementation Model; Open Engineering, v.6, n.1, p.397-406, 2016.

ABREU, A., CALADO, J.M.F., PÊGO, EDUARDO, Planeamento da manutenção preventiva usando algoritmos genéticos. ICEUBI2015 - International Conference on Engineering, Engineering for Society, 2 - 4 de Dezembro, Covilhã, Portugal, 2015.

ABREU, A.; CAMARINHA MATOS, L. M., An Approach to Measure Social Capital in Collaborative Networks. In IFIP International Federation for Information Processing; Adaptation and Value Creating Collaborative Networks; L. M. Camarinha-Matos, Alexandra Pereira-Klen, Hamideh Afsarmanesh (Eds.); (Germany: Springer), p. 29-40, 2011.

AHMED, A.; KAYIS, B.; Amornsawadwatana, S. A review of techniques for risk management in projects. Benchmarking International Journal, v.14, n.1, p. 22-36, 2007.

ARSLANKAYA, S.; ATAY, H. Maintenance Management and Lean Manufacturing Practices in a Firm Which Produces Dairy Products. Procedia - Social and Behavioral Sciences, v.207, p. 214-224, 2015

BASS, ISSA. Six sigma statistics with Excel and Minitab. v.7 New York, NY, USA: McGraw-Hill, 2007.

BUSSEL, G.; ZAAIJER, M., Reliability, Availability and Maintenance aspects of large-scale offshore wind farms, a concepts study International Conference on Marine Renewable Energies, Newcastle, UK; 2001

CAMARINHA-MATOS, L.M.; MACEDO, P.; ABREU, A., Analysis of core-values alignment in collaborative networks. In IFIP International Federation for Information Processing, v.283; Pervasive Collaborative Networks; Luis M. Camarinha-Matos, Willy Picard (Eds.); (Boston: Springer), p. 53-64, 2008.

CaMARINHA-MATOS, L. M., ABREU, A. Performance indicators based on collaboration benefits, Working Conference on Virtual Enterprises. Springer, Boston, MA, 2005.

GUPTA, PRAVEEN. Six sigma business scorecard. Perspectives on Performance, 10, 2004

GUPTA, PRAVEEN. Six Sigma business scorecard. McGraw Hill Professional, 2006.

KAPLAN, ROBERT S., AND DAVID P. NORTON. The strategy-focused organization: How balanced scorecard companies thrive in the new business environment. Harvard Business Press, 2001.

MONTGOMERY, DOUGLAS C. Introduction to statistical quality control. John Wiley \& Sons (New York), 2009.

PEREIRA ZL, REQUEIJO JG. Qualidade: Planeamento e Controlo Estatístico de Processos, Co-edição da Fundação da FCT/UNL e da Editora Prefácio, Lisboa, 2008

REQUEIJO, JOSÉ; ABREU, A., Aplicação do Desenho de Experiências na Definição de Estratégias Operacionais. ICEUBI2013 - International Conference on Engineering, Engineering for Economic Development, UBI Editions, ISBN:978-989-654-20-0, 27 - 29 de Novembro, Covilhã, Portugal, 2013 
REQUEIJO, J.; ABREU, A.; MATOS, A., Statistical Process Control for a Limited Amount of Data - ICORES 2014 3rd International Conference on Operations Research and Enterprise Systems 06 - 08 March, ESEO, Angers, France. p. 190-195, 2014.

RYAN, T. P. Statistical methods for quality improvement. John Wiley \& Sons, 2011.

SUNG, P. A. Six Sigma for Quality and Productivity Promotion. Asian Productivity Organization, Tokyo, 2003.

SZKODA, M., Assessment of reliability, availability and maintainability of rail gauge change systems. Eksploatacja i Niezawodnosc - Maintenance and Reliability, v.16, n.3, p.422-432, 2014.

TENERA, A., ABREU, A., A TOC perspective to improve the management of collaborative networks. In IFIP International Federation for Information Processing, v.283; Pervasive Collaborative Networks; Luis M. CamarinhaMatos, Willy Picard (Eds.); (Boston: Springer), p. 167-176, 2008.

EMOVON, I.; NORMAN, R.; MURPHY, A. Elements of Maintenance Systems and Tools for Implementation within the framework of Reliability Centred Maintenance - A Review. Journal of Mechanical Engineering and Technology, v.8, n.2, p. 1-34, 2016.

TONT, G.; ILIESCU, M.; TONT, D., A Methodology of Availability Assessment for Complex Manufacturing Systems. Wseas Transactions on Systems, v. 7, n.6, p. 822-832, 2008.

MUCHIRI, P.; PINTELON, L.; GELDERS, L.; MARTIN, H. Development of maintenance function performance measurement framework and indicators. International Journal of Production Economics, v.131, n.1, p.295-302, 2011. 